\title{
The Magical Realism of Body Counts: How media credulity and flawed statistics sustain a controversial policy
}

By

Muhammad Idrees Ahmad, PhD, MPA

Lecturer in Digital Journalism

Communications, Media \& Culture

School of Arts \& Humanities

University of Stirling

Stirling, FK9 4LA, Scotland

p: +44 7708385065

e: mia2@stir.ac.uk

w: http://wp.me/PpCFZ-8VK

t: @im_pulse

Dr. Muhammad Idrees Ahmad is the author of The Road to Iraq: The Making of a Neoconservative War (Edinburgh University Press 2014). He writes for The Atlantic, The New Republic, The Nation, Los Angeles Review of Books, Al Jazeera, The National, Vice News, In These Times, Le Monde Diplomatique, Die Tageszeitung (TAZ), Adbusters, Guernica, London Review of Books (Blog), Asia Times, IPS News, Political Insight, The Drouth, Canadian Dimension, Tanqeed, Variant, etc. He has appeared as an on-air analyst on Al Jazeera, the BBC, RAI TV, Radio Open Source and several Pacifica Radio channels. 


\title{
The Magical Realism of Body Counts: How media credulity and flawed statistics sustain a controversial policy
}

\author{
Muhammad Idrees Ahmad \\ University of Stirling, UK
}

\section{Abstract}

The drone war in Pakistan poses considerable humanitarian, legal, ethical and political challenges. The tactic is controversial and has been condemned by the UN's special rapporteur on extrajudicial killings. Yet, polls have shown high support for the tactic in the US (and to a lesser degree in the UK). Much of this has to do with the media reporting on the war, which consistently underestimates its human toll. Dubious statistics have sustained the image of a surgical war with little collateral damage. But as this article shows, there are reasons to doubt these numbers. The article argues that two interrelated factors have contributed to a flawed accounting of the war's human toll: 1) rituals of objectivity that privilege "official sources"; 2) fetishizing of statistics as hard facts without regard for the underlying data. The coverage has also been distorted by news values that downplay or ignore deaths in distant places unless they cross an inordinately high threshold.

\section{Keywords}

Drones, Statistics, News Values, Sourcing, objectivity, propaganda, secrecy, technology, military.

\section{Introduction}

During US president Barack Obama's first term in office, an internal debate between proponents of counterinsurgency, with its demand for large-scale troop commitments, and counterterrorism, with its reliance on Special Forces and precision weapons, was resolved in favour of the latter (Woodward, 2010). The unmanned aerial vehicle (UAV), commonly known as the 'drone', emerged as a staple of this policy. By 2013, its use was so extensive that in a speech, Obama confessed that he had come 'to view drone strikes as a cure-all for terrorism' (Obama, 2013).

In the ten years between June 2004 and February 2015, the United States used drones to launch 413 missile strikes in Pakistan. According to the Bureau of Investigative Journalism (BIJ), the strikes have reportedly killed 2,438-3,942 people, 416-959 of them civilians, 168-204 children. Fewer than 4 percent of those killed have been identified as members of al Qaeda (Serle, 2014); only 2 percent as 'high value targets' (Kaag \& Kreps, 2014). The identity of the majority remains unknown. Despite the highly permissive criteria used by the US in selecting its targets, the media has by and large accepted official claims regarding the status of those killed. The statistics about the drone war had by and large eluded scrutiny until June 2011, when this writer wrote a series of articles casting doubt on them (see Ahmad, 2011). Soon afterward, the BIJ's drones project was launched, which has evolved into a comprehensive and relatively more reliable database of information on the attacks.

The drone war has been precedent setting. Its consequences for the international order are immense (Boyle, 2013; Kaag \& Kreps, 2014). The technology is relatively inexpensive and easily replicable. By November 2013, 87 states (and even some non-state actors) were in possession of 
drone technology (Taylor, 2013). The capacity to deploy them offensively across international borders will soon be common.

Through credulity and neglect, the media have indirectly allowed things to come this far. A reckoning is necessary. This article is a contribution to that end. It critically appraises the media's coverage of the drone war, focusing on the statistics that have been used to assess the success or failure of this policy. The article aims to show the limitations of such numbers and the challenges of compiling them. It identifies two interrelated factors that have contributed to the mostly uncritical media coverage and, consequently, to the relatively muted public response:

1. Rituals of objectivity that allow journalists to mask credulity

2. Fetishizing statistics as hard facts, regardless of the credibility of underlying data

This has consequences. As Galtung \& Ruge (1956) note, prevailing news values place an inordinately high threshold on the number of deaths in a distant event for the story to merit coverage. The lowballing of civilian deaths by official sources in the initial reports and their aggregation into seemingly authoritative statistics by institutions like NAF relegates the issue and denies the public an opportunity to fully assess its humanitarian and ethical implications.

To illustrate the point, this article analyses the reportage of two leading liberal dailies, The New York Times and The Guardian, for the first quarter of 2010, the year with the highest number of drone strikes. It shows that (a) in most cases, the media accepts casualty figures from unnamed official sources, disregarding possible conflicts of interest; and (b) that the coverage is selective. This in turn informs the statistics that rely on these media reports. The article assesses the figures produced by the three main tracking agencies - the New America Foundation (NAF), the Long War Journal (LWJ) and the $\mathrm{BIJ}$ - and argues that by uncritically accepting the initial claims, the NAF and the LWJ - the two most cited sources in the US (Stanford-NYU, 2012) - have contributed to a serious undercounting of the war's human toll and created a misleading perception of the war as precise, surgical and discriminating. Indeed, this has allowed the Obama administration to confidently assert that the 'drone strikes are legal, they are ethical, and they are wise' (Jay Carney quoted in Kaag \& Kreps, 2014). Obama has personally justified the attacks on the ground that they are 'effective'and 'legal' (Obama, 2013).

The aim of this article is not to dismiss media coverage in toto. Its subject is only a particular mode of coverage. The initial reports on drones have to deal with the scarcity of information and lack of access: they are necessarily tentative. Subsequent reports that have parsed and corroborated information are often more substantive. Indeed, the two newspapers analysed here have also produced some of the most insightful reporting on the drone war. Less excusable, however, are the methods of the data aggregators who, with the exception of BIJ, continue to rely on initial reports alone.

In Gabriel Garcia Marquez's magical realist masterpiece One Hundred Years of Solitude, a deceased gypsy named Melquiades returns to life because he can no longer bear the tedium of death. Similar resurrections have also happened in the drone war when so-called 'high value targets' have been found walking long after the media reported them dead in a drone strike. Garcia Marquez said that he owed his style - a combination of fantastic scenarios with painstaking detail - partly to his grandmother who would tell the most improbable stories with a perfect deadpan. The same 
approach seems to obtain in the production of drone statistics where the apparent rigour of method obscures a fantastical underlying reality.

\section{The Numbers Game}

Statistics are an authoritative way of describing the scope of a social or political problem. Numbers convey a sense of precision. We live in 'a hyper-numeric world preoccupied with quantification'; 'in practical political terms,' argue Andreas \& Greenhill, 'if something is not measured it does not exist...if there are no "data," an issue or problem will not be recognized, defined, prioritized, put on the agenda, and debated' (2010: 1). Statistics, writes Best, can 'become weapons in political struggles over social problems and social policy' (2001: 10). 'The creation, selection, promotion, and proliferation of numbers are thus the stuff of politics' (Andreas \& Greenhill, 2010: 2).

Statistics are not always neutral: they are inscribed with the interests of those producing them. Supporters and opponents of policies will inflate or underestimate numbers based on what best serves their preferred policy (Best, 2001: 10). 'Because quantification is politically consequential, it can also be highly contentious,' write Andreas \& Greenhill. 'Both proponents and opponents of any given policy will marshal reams of data to bolster their position and to weaken support for rival positions.' (2010: 2)

Statistics can have concrete policy consequences. Because they 'shape both public and closed-door policy debates', they 'serve to legitimize some positions and undercut others' (Ibid: 135). Data is often politicized. For the powerful, it can become a tool for maintaining the status quo; for the activist, a potential instrument of change. This becomes particularly significant in the case of conflicts as 'prevailing estimates of the scale of violence, its complexion, and its measurable consequences undeniably play a role in shaping policy priorities and objectives' (Ibid). Statistics, therefore, can potentially prolong or end a conflict. If politicians or their publics have a distorted view of a war's progress - an inevitability since inflating success and downplaying setbacks become a state imperative to maintain military morale and public support - it pre-empts any reconsideration of the policy.

The US government has made confident claims for the extraordinary precision of its robotic weapons. In 2011, US president Obama's chief counter-terrorism adviser John Brennan insisted that in the drone war, 'nearly for the past year there hasn't been a single collateral death'. Obama also vouched for drone's accuracy. 'Drones have not caused a huge number of civilian casualties', he claimed: 'This is a targeted, focused effort at people who are on a list of active terrorists trying to go in and harm Americans'. It is possible that Obama believes these claims. It will not be the first time that the details of a covert operation are withheld from a president to guard against possible perjury. Ronald Reagan's advisers had done the same during the Iran-Contra affair. But media reporting has likely reinforced Obama's beliefs.

In accepting claims from the prosecutors of the war, the media overlooks potential conflicts of interests. Official claims, by virtue of being official, are deemed more credible. For Tuchman (1972), this dispensation has to do with a certain notion of 'objectivity' that privileges form over content. 'Objectivity' in this reading comprises strategic rituals that protect journalists from flak or libel. All journalists are pressed by deadlines and when an official makes a claim, a journalist might not have the time to Iocate adequate information with which to assess the extent to which the claims is a 
"fact"'. But under such circumstances, Tuchman (1972) notes, 'newspapermen regard the statement " $X$ said A" as a "fact", even if " $A$ " is false.' Outcomes become secondary to the process.

The reliance on official sources gives journalists cover; but it also allows officials to potentially abuse secrecy privileges. Where information is unavailable, controlled, suppressed, or otherwise scarce, those with exclusive claim to it assume greater authority. The limited supply of information inflates its value, and concerns about its quality are deferred. This allows prosecutors of secretive campaigns to shape narratives and elude scrutiny. Their claims of success face no immediate challenge. By the time they are refuted, the news cycle has moved on. If failure is reported at all, it is relegated to the back pages. 'Falsehood flies,' wrote Swift (1710), 'and the Truth comes limping after it; so that when Men come to be undeceived, it is too late; the Jest is over, and the Tale has had its Effect'.

Reality is further distorted when this defective reportage becomes the basis for measuring a policy's impact. By passing through the legitimizing process of 'calculative practices', bad data is laundered into ostensibly credible numbers; and, regardless of a statistician's good faith, the outcome deceives. For the media, statistics represent 'hard facts'-regardless of their provenance. They are used as a measure of the scale of a problem - social, political, or economic (Best, 2001: 17-18). When organisations like NAF and LWJ compile these unverified 'facts' into elaborate statistics that systematically undercount casualties, they distort perceptions and influence public attitudes.

Galtung \& Ruge (1965) note that when it comes to foreign conflicts, an incident is considered newsworthy only if it crosses a certain fatality threshold. Though the participation of the US has made the drone story relevant to the US public, the deaths occur on a small enough scale to let them escape the scrutiny that they might cumulatively merit [It bears noting that the US public is considerably more sceptical of the drones being deployed at home (Kaag \& Kreps, 2014)]. Instead of a big violation, the campaign is a prolonged drip of comparatively small infractions that keeps it simmering below the opprobrious threshold.

The attacks also occur at a steady enough frequency that they have lost the element of the unexpected-a factor that earlier brought them some attention. A fascination with the technology remains, but this focuses on its presumed efficacy and precision-notions that are reinforced by the low casualty figures. The human cost is occasionally broached but often as a public relations problem. As a consequence, the drone war for the most part has failed in the US to rise to the level of a public issue. It only entered the national debate after a leaked Justice Department document revealed that the Obama administration has legalized killing Americans abroad if they 'present an imminent threat to national security' (Isikoff, 2013). 


\section{THE BUREAU OF INVESTIGATIVE JOURNALISM}

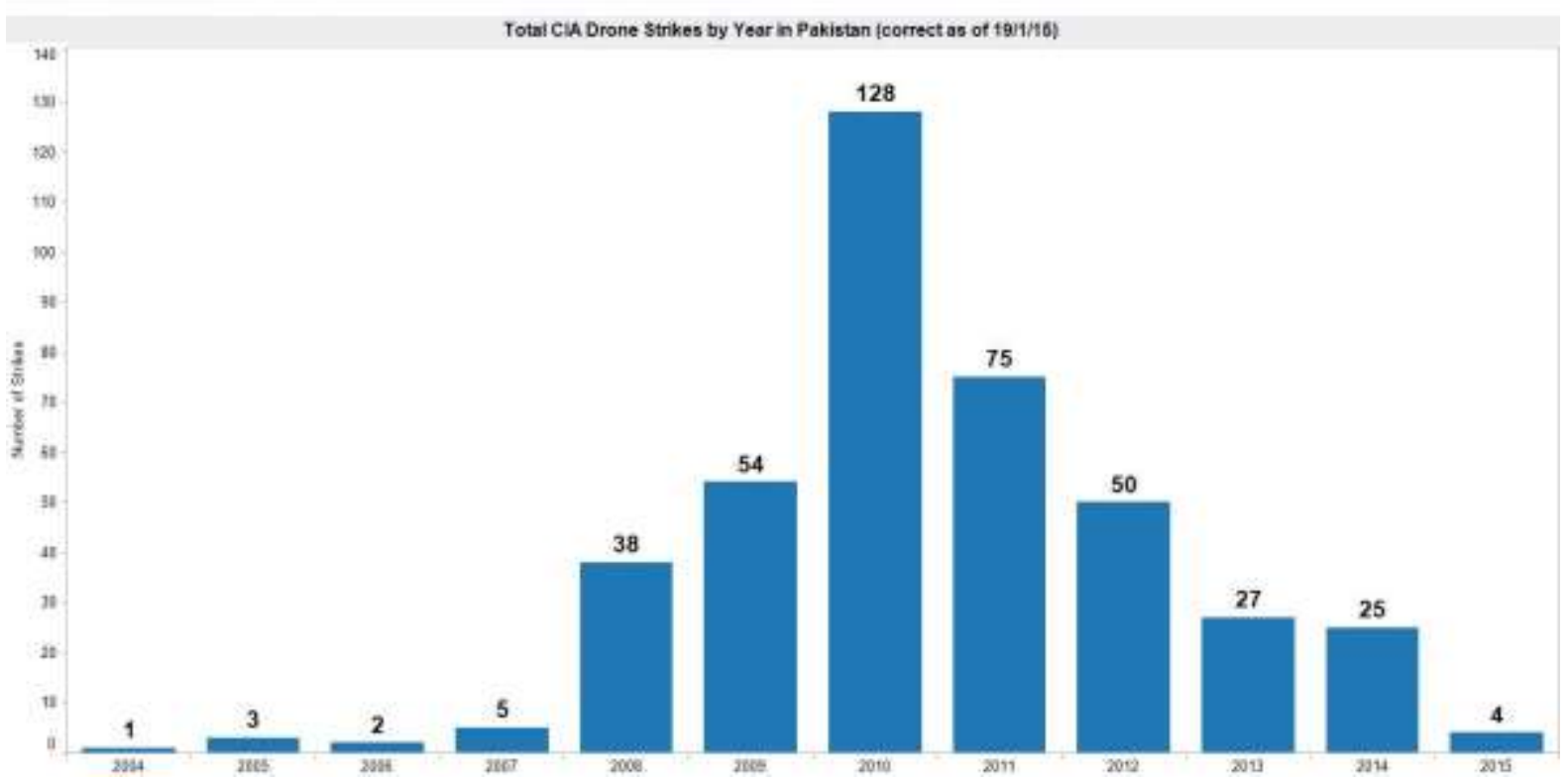

Figure 1: Total drone strikes in Pakistan (Data and graphic by the Bureau of Investigative Journalism)

Since 2012, the policy has been significantly rolled back. This is in part a response to the growing anger worldwide where American official claims have less purchase. In the US, the propaganda has succeeded. Polls show a majority of Americans supporting the drone war (Fuller, 2014); but polls are often themselves part of the propaganda Kreps (2014). The fact that this war is cheaper and that its human and political costs borne by others has no doubt helped. So perhaps has the presumed surgical nature of the war.

For the public, the seeming precision of statistics bears the semblance of hard facts-a semblance that is aided by 'widespread confusion about basic mathematical ideas' (Best, 2001: 19-20). A consequence of this innumeracy, writes Best, is that 'many statistical claims about social problems don't get the critical attention they deserve' (Ibid). Instead, he writes, 'we tend to regard statistics as though they are magical, as though they are more than mere numbers'.

We use statistics to convert complicated social problems into more easily understood estimates, percentages, and rates. Statistics direct our concern; they show us what we ought to worry about how much we ought to worry. In a sense, the social problem becomes the statistic and, because we treat statistics as true and incontrovertible, they achieve a fetishlike, magical control over how we view social problems. We think of statistics as facts that we discover, not as numbers we create" (Ibid: 160).

Statistics, in this sense, are a social product. They often reflect the culture, structure and practices of the organizations producing them (Best, 2001: 25-26). Even when produced by experts-which they often are-they involve myriad choices that shape the final outcome. They are necessarily a simplification - and, sometimes, they can contribute to a simplified, even superficial, understanding of complex political realities (Ibid: 161). This is particularly true for the drone war. If society uses statistics as a measure of the magnitude of a problem, then a systematic undercount of the human 
cost of the strategy has forestalled adverse public reaction by engendering passivity and political inertia. This has helped prolong a precedent-setting policy with dangerous global consequences.

\section{The Rituals of Objectivity}

In 2002 when the US launched its first drone strike in Yemen, the press reported it as a Yemeni operation (Mazzetti, 2013). Likewise on June 24, 2004, when the first US drone strike was launched in Pakistan, the press ascribed the attack to the Pakistani military (Ibid). In both cases, the media relayed what was in effect a cover story. But the drone war was in inception and the media had little cause for doubt. This state of affairs prevailed well into 2007. By 2008, however, the drone operations were no longer a secret. With presidential candidates openly speaking about them, the existence of the campaign could no longer be denied (Woodward, 2010). However, little changed when it came to reporting the effects of the bombings. With FATA out of bounds, the press relied almost exclusively on official sources for casualty figures. Most of these were Pakistani, some of them American, all of them anonymous. The media appeared unfazed by the apparent conflict of interests. Nor did it question the targeting criteria.

This pattern is consistent across the news media. In the aftermath of each attack, journalists follow certain strategic rituals that allow them to report where verifiable information is scare. Since the strike zones are off-bounds to international journalists, the effects of the bombings are impossible to verify-at least in the short term. However, there are always officials available to volunteer information about the strikes and their purported targets. In the absence of other details, this appears useful. In some cases, the official claims are reported as fact; in others, the only fact reported is that an official claim was made. The officials are invariably anonymous. Their credibility might be impossible to establish but, by virtue of their governmental affiliation, they sound more credible than unaffiliated witness. To be sure, some journalists make an effort to highlight the doubtful nature of the information. Some use conspicuous quotation marks to emphasize the subjective nature of the information. The effect, however, is the same since, once in print, the claims become the basis for statistics about the conflict.

It is instructive in this regard to consider the reporting of two of the world's leading dailies, The New York Times and The Guardian. Both papers have a liberal orientation and it is not unreasonable to assume that their coverage of the drone war will be as critical, if not more, than their right of centre counterparts. The sample is taken from the first quarter of 2010, the year in which the highest number of drone strikes was launched. The aim of this exercise is not to present an exhaustive list of the sources that the media uses in its reportage-that would be tedious and unnecessary. The aim is to show a consistent pattern that is generalizable to the media's wider coverage of drones. The sample makes clear that in reporting drone deaths, anonymous official sources predominate.

In the period under study, 69 stories were published that mentioned drone strikes in Pakistan, with The New York Times publishing twice as many (46) as The Guardian (23). But most of these were stories that merely discussed drone attacks; only 14 reported a drone strike as news.

1. January 1: the New York Times reports that two 'militants' have been killed in strike according to 'a security official in the region, who declined to be identified'. ${ }^{1}$

2. January 7: the New York Times reports a dual strike, one of which targeted rescuers aiding those hit in the first. The report quotes 'senior government officials'; one claims 17 died and 
the other declares that 'the target of the attack was a base frequented by foreign fighters, and that about two dozen people had been killed'. 'Speaking on the condition of anonymity', both official claimed that 'foreign militants were among the dead'.

3. January 14: The Guardian reports a drone strike that morning in which 'Twelve militants were reportedly killed'. It quotes two unnamed intelligence officials but gives no source for the claim about the deaths.

4. January 15: The New York Times reports the previous days strike without any additional information about the victims.

5. January 16: The New York Times revisits the January 15 strike and, quoting 'two Pakistani intelligence officials', alleges that among those killed was a Palestinian militant Jamal Saeed Abdul Rahim. However, 'an American intelligence official' who 'spoke on the condition of anonymity' says 'he could not yet confirm the Pakistani claim'.

6. January 18: The New York Times reports another attack that 'killed as many as 15 people' quoting 'Pakistani security officials'.

7. January 22: The New York Times reports a strike that, according to 'a Pakistani intelligence official and a local television report', killed a Filipino militant.

8. January 31: The New York Times reports a strike in which three missiles 'killed 15 militants in North Waziristan' according to unnamed 'Pakistani security officials'.

9. February 3: The New York Times reports the heaviest strike yet in which eight drones fired 17 missiles, reportedly killing 10 . The article quots a 'security official' to claim that the 'targets were bases and training camps used by his militants'. The article also added: 'American and Pakistani officials said this week they believed that Mr. [Pakistani Taliban chief Hakimullah] Mehsud died of wounds sustained in a drone strike in January and was recently buried.' ${ }^{2}$ Notably, the article adds: 'In the past, people involved in rescue efforts have also been the target of drone strikes, so local residents now avoid visiting the sites of attacks. This adds to the scarcity of information about the targets and casualties.'

10. February 15: the New York Times reports that 'at least six militants' killed according to unnamed 'Pakistani security officials'.

11. February 16: the paper carries another story that reported 'three militants' killed. No source was cited.

12. February 20: the Guardian reports a strike that, according to 'two officials', killed 'Muhammad Haqqani and three other close associates of the Taliban leader'. This time, however, a 'local commander of Pakistani Taliban' corroborates the story. The New York Times attributes the same story to 'several Pakistani security and intelligence officials, residents in Waziristan and a friend of the commander's family'.

13. February 25: the New York Times reports a drone strike that killed 'eight militants' according to 'a Pakistani security official and residents'.

14. March 17: the New York Times a wire story reporting 'at least seven militants' killed. The claim is attributed to 'an intelligence official and an army official'. ${ }^{3}$

15. March 18: the paper reports for the first time on a March 8 strike that killed Hussein alYemeni, an 'Al Qaeda planner and facilitator,' according to 'a United States counterterrorism official' who spoke 'on the condition of anonymity'. 
According to the $\mathrm{BIJ}$, there were 30 drone strikes in this quarter. But The New York Times covered 12 and the Guardian only 1 . The stories are primarily attributed to unnamed officials; only two are corroborated by additional sources. Most of the officials cited are Pakistani.

Regardless of their shortcomings, these claims feed into the statistics produced by data aggregators. In an analysis of NAF's datasets for 2012, a Stanford-New York University study found that

anonymous officials are cited as a source for the allegation of the number of 'militants' killed in $88 \%$ of articles referenced by New America Foundation, and are the only source of this information in $74 \%$ of the articles... This heavy reliance on anonymous officials is troubling given the demonstrated unreliability of official reporting (Stanford-NYU, 2012).

The study also addressed the related question of identification. Neither the US nor the Pakistan government has a mechanism for verifying the identity of those killed in drone strikes. Under the expanded authority granted by Barack Obama, drone strikes aren't confined only to high value targets; anyone suspected of being a militant based on 'pattern of life' analysis, collected through aerial surveillance, can be killed in what are known as 'signature strikes' (Boyle, 2013). In the tribal areas, where traditionally most adult males carry guns and ammunition, this has made everyone a potential target (Cloud, 2010). A year before Osama bin Laden was killed, a CIA officer told Jane Mayer of the New Yorker, that because of the drone surveillance, 'no tall man with a beard is safe anywhere in Southwest Asia' (Mayer, 2009).

This permissive atmosphere has created a mentality in which the targets are seen as nothing more than insects to be quashed. The CIA uses the term 'bug splat' to estimate the blast radius of its Hellfire missiles (Mackey, 2014). For the drone operators too the war has a remote quality. Indeed, the military has essayed to recruit gamers as potential drone operators (Schei, Loge, Phillips et al, 2015). The similarities are not lost on the operators. 'It's like a video game,' one young drone operator told Singer (2009), 'It can get a little bloodthirsty. But it's fucking cool.'

The respected Pakistani journalist Rahimullah Yusufzai told this author that it is no longer possible for foreign journalists to travel to the tribal region and, as a result, most of the reporting comes from a handful of stringers based in Miranshah and Mir Ali, the FATA region's two main cities. Even journalists based in FATA have to call up the military's press office for information on strikes that occur outside the main towns. Noor Behram, a local journalist, is an exception. He managed to photograph the aftermath of 27 drone attacks in North and South Waziristan between November 29,2008 , and June 15,2011 . The picture he paints is at odds with the rosier one presented in the western media. 'For every ten to 15 people killed,' he told the Guardian, 'maybe [the drones] get one militant' (Shah \& Beaumont, 2011).

The reliance on Pakistani officials is particularly problematic. The Pakistani government is an active partner in the drone campaign that the Pakistani public overwhelmingly opposes (Mazzetti, 2013). As a result, the government is reluctant to acknowledge civilian casualties lest it further inflame public opinion. This eagerness to declare all those killed 'militants' is acknowledged in The New York Times report on the January 16 strike: 'American officials have been more cautious than their Pakistani counterparts in declaring that American drone strikes had killed militants' (see note 1). This is a rare disclaimer. In most cases, claims from unnamed officials are reported as fact. Nor are they interrogated on what constitutes a 'militant'. 
Definitions are important, writes Best, they 'specify what will be counted' $(2001: 44,45)$. In this case, they also specify what isn't counted. If 'militant' is defined expansively, then the space for being counted as a civilian shrinks. This was made dramatically clear in the New York Times' revelation that the US president Barack Obama had 'embraced a disputed method for counting civilian casualties' that according to several administration officials 'in effect counts all military-age males in a strike zone as combatants...unless there is explicit intelligence posthumously proving them innocent' (Becker \& Shane, 2012).

Even among combatants, International Humanitarian Law (IHL) prescribes discrimination. The International Committee of the Red Cross (ICRC)'s Interpretive Guidance on the Notion of Direct Participation in Hostilities under IHL draws a distinction between 'direct and indirect participation in hostilities and between legal and illegal targets'. It stresses that 'direct causation should be understood as meaning that the harm in question must be brought about in one causal step' (quoted in Kaag \& Kreps, 2014). However, as Kaag \& Kreps note, most of the 'militants' killed in Pakistan are 'lower-level foot soldiers...who are "neither presently aggressing nor temporally about to aggress."' Consequently, they argue, the drone war satisfies neither the jus ad bellum (right to war) nor jus in bello (conduct in war) principles of a just war. The administration's claims to the drone war's legality are therefore void (a view confirmed by the UN's Rapporteur on Extra Judicial Killings, Ben Emmerson QC).

The administration has tried to circumvent legal barriers by adopting a definition of 'imminent' that is as expansive as its definition of a 'militant'. The aforementioned leaked Justice Department memo reveals that for a threat to be deemed imminent, it 'does not require the United States to have clear evidence that a specific attack on U.S. persons and interests will take place in the immediate future' (Isikoff, 2014).

\section{The vicious circle}

The first attempt at measuring the drones' human toll wasn't made until the autumn of 2009 when in an article for the Pakistani daily The News, a journalist estimated that between January 14, 2006, and April 8, 2009, 60 drone attacks had killed 701 people of whom only 14 were on the US 'high value target' (HVT) list (Mir, 2009). Based on this, the journalist concluded that all the rest -98 percent of those killed - were civilians. The estimate was given credence when two respected figures from the US security establishment - the former Ranger Andrew Exum and General David Petraeus's counterinsurgency advisor David Kilcullen (2009) - repeated it in an article for the New York Times. The figures were challenged. Though the US had identified only 14 known militants among the 701 people killed in Pakistan, critics argued this was not sufficient to assume that everyone else was a civilian (Fair, 2010).

On October 1, 2009, in response to Exum and Kilcullen, an analysis was published by LWJ, an initiative of the Foundation for Defense of Democracies, a neoconservative think tank founded two days after $9 / 11$ to promote the 'global war on terror'. By 'adding up the number of civilians reported killed from the media accounts of each attack,' it concluded, 'only $9.6 \%$ of the casualties reported have been identified as civilians'. Nonetheless, it admitted that the numbers were 'undoubtedly a low estimate' (Roggio \& Mayer, 2009). This analysis was followed the same month by NAF, a Washington-based liberal think tank, which, using a similar method determined civilian 
deaths since 2006 to be 'in the range of 250 to 320, or between 31 and 33 percent' (Bergen \& Tidedemann, 2009).

Both organisations maintain constantly updated databases, and it has become di rigueur for journalists to cite their estimates in discussions of the drone war. Both employ a seemingly rigorous method, and the apparent precision of the numbers lends the estimates an air of credibility. Little attention is paid to the fact that the estimates rely entirely on media reports whose own credibility - as noted earlier - is often in doubt.

The reliance on media reports is problematic because initial claims have frequently proved false. Consider the following:

- In the first quarter of 2010 (the sample analysed earlier), the New York Times and The Guardian published several articles speculating that Hakimullah Mehsud, the leader of the Pakistani Taliban (TTP), had been killed in two separate strikes. He would be pronounced dead again on January 12, 2012. Mehsud, in fact, would go on to elude drones until November 1, 2013, when one would finally kill him.

- In September 2009, the CIA claimed that it had killed the Pakistani Taliban leader llyas Kashmiri along with two other senior leaders in North Waziristan. Kashmiri wasn't killed until June 3, 2011.

- Baitullah Mehsud, the former commander of the TTP, was reported dead in drone strikes on 16 different occasions before his actual death on August 5, 2009.

- Mullah Sangeen also resurrected twice. The June 23, 2009 attack on a funeral procession that killed Sangeen was supposed to have killed Baitullah Mehsud. It killed 83 people; Mehsud wasn't one of them (see Ahmad, 2011). ${ }^{4}$

In 2010, a case-by-case analysis of nine attacks by the Campaign for Innocent Victims in Conflict (CIVIC) uncovered 30 previously unreported civilian deaths, including 14 women and children (Rogers, 2010).

This has done little to encourage caution among the tracking agencies. As the following examples show, their methods are less than rigorous. On January 13, 2006, a drone struck the village of Damadola in Bajaur, killing 18 villagers, mainly women and children. Pakistani and US officials claimed that four 'al-Qaeda terrorists' were among the dead. The claim was later retracted (Whitlock, 2007). But the NAF continued to list all 18 as 'militants'. On October 30, another drone hit a seminary in Chenagai, also in Bajaur, killing 82 people, including 69 children (Lamb, 2006). But the NAF recorded 'up to 80 ' militants killed in the strike with no civilian casualties. (NAF would not correct this until August 2012, after it had been challenged both by this author and the BIJ).

A Stanford-NYU (2012) study found more instances of NAF overlooking known civilian casualties. An October 31, 2011 strike killed 16-year old Tariq Aziz and his cousin Waheed Khan - a fact widely reported in western and Pakistani media. But the NAF entry for the attack mentioned no civilian casualties. A June 15, 2011 attack killed four civilians but the NAF entry lists all the dead as 'militants'. Likewise, no civilian casualties are recorded for an August 14, 2010 attack in which an AP investigation had confirmed at least 7 civilian deaths. More interestingly, until the autumn of 2012, the NAF database showed that drones had killed no civilians that year. But in a May 24, 2012 strike alone, Pakistan's main English daily The News and UK's Channel 4 had reported 3-8 civilian deaths 
based on the testimony of named eyewitnesses. NAF partially corrected its record only after being challenged by the BIJ and the Stanford-NYU team.

There were more known civilian deaths that the NAF has yet to acknowledge.

- An Amnesty International report revealed that on July 6, 2012, a drone strike in the remote village of Zowi Sidgi killed 18 male labourers, including one child (Amnesty, 2013). The attack followed what the CIA calls a 'double tap' policy, with a follow-up strike killing 8 rescuers who had gathered to help those targeted in the initial strike. The NAF database lists all those killed as 'militants'.

- On July 23, 2012, another drone struck a group of 5 Taliban, but with a 'double tap', the drone also killed 6 civilian rescuers. The NAF lists all those killed as 'militants'.

- On October 24, 2012, a drone strike killed the 68-year-old grandmother Mamana Bibi and injured several members of her family in the village of Ghundi Kala. Though the NAF database mentions one civilian death, it also lists 0-4 'militants' killed. A detailed Amnesty investigation found 9 injured children but no militants. (One of the children, 8-year-old Nabeela, would later testify before the US congress).

- The same pattern obtains for NAF's coverage of 2011. It lists 57-65 civilians killed for that year. But an extensive study by the Columbia Law School's Human Rights Clinic found that according to available reports, the actual number was between 72-155 (Columbia, 2012).

Mindful of NAF's shortcomings, in the latter half of 2011, the London-based BIJ launched a more expansive investigation into the drone war. Like NAF and LWJ, BIJ also relies primarily on media reports; but unlike them, it does not confine itself to initial reports alone-it also analyses stories written days, weeks, even months after the initial incident. The BIJ also works with journalists, researchers, and lawyers representing the affected civilians to develop a more rigorous accounting of those being killed. It has also distinguished itself from its predecessors in terms of the categories it uses for its analysis. While the LWJ uses a simple distinction between 'militant' and 'civilian', the NAF database for its first few years had no category for 'civilian' - only 'militant' and 'others' (It refined its categories to 'militant', 'civilians' and 'unknown' sometime after this author drew attention to it in an Al Jazeera article). By contrast, the BIJ tries to accurately establish the actual number of drone strikes, the total number of people killed, the confirmed number of civilians among them, and how many of those are children (all are undercounted by LWJ and NAF).

The BIJ, however, admits that its figures for civilian casualties are a 'conservative estimate'. It only counts as a civilian someone whose status it can confirm through multiple sources. In most cases this is impossible since access to the affected region is controlled by the Pakistani military, which is party to the 'global war on terror'. The BIJ is further hampered by an expansive definition of the label 'militant' that requires that all military age males be treated as combatants until proven innocent. What the BIJ provides is therefore little more than a baseline estimate of the civilians killed. Yet, this hasn't prevented the Obama administration from accusing the BIJ of wanting 'nothing more than to malign these efforts and help Al Qaeda succeed' (Shane, 2012).

The Obama administration and its Pakistani counterparts have gone out of their way to obscure realities on the ground. Collecting data under these circumstances is a challenge. The three projects - the BIJ more so than the NAF and LWJ-have been useful in giving a broad picture of an 
otherwise shadowy war. But because of fallible methodology, structural constraints and ideological limitations, these statistics present only a partial picture. All three projects acknowledge the limitations of their method. But when the media reports these without the necessary qualifiers, it misinforms the public and forestalls challenges to the policy. ${ }^{5}$

\section{Conclusion: A Moral Hazard}

Polls in the US have consistently registered high levels of support for the drone policy (Fuller, 2014). But polls may or may not reflect the actual strength of feeling. Kaag \& Kreps (2014) have shown that poll results have been decisively skewed by the way pollsters frame questions. For example:

A typical formulation is the following from a Yougov/Economist poll: 'Do you approve or disapprove of the Obama Administration using drones to kill high-level terrorism suspects overseas?' Or another (Gallup): 'Do you think the US government should or should not use drones to ... launch airstrikes in other countries against suspected terrorists?' And the NBC/Wall Street Journal version: 'Do you favor or oppose the use of unmanned aircraft, also known as drones, to kill suspected members of Al Qaeda and other terrorists?' (Ibid)

None of these questions acknowledge the disputed status of the targets. Might the answers be different if the respondents knew that only 2 percent of those killed were HVTs?

Potential outrage appears to have been attenuated by the media's adherence to a notion of objectivity that confuses credulity for impartiality. Professionalism does not trump public service responsibilities. The public will be denied a fuller picture of the war until the media shifts the onus onto its prosecutors. One way to hold the administration accountable would be to assume all those killed innocent until the administration is able to prove otherwise. The media could demand fuller explanation for each strike and its intended targets. It can also insist on demanding legal justifications for the strikes under IHL. Individual journalists must also be held to account but without forgetting the constraints they work under. They work to deadlines and, with a fast moving news cycle, they cannot all be expected to find multiple sources for events happening in remote regions. But editors can ensure accuracy by systematically adding caveats to all official claims until they have been corroborated by independent sources.

This article is not an indictment of the media in general or the technology in particular. The focus is specific malpractices. There is little doubt that targeting technologies have improved immensely over the past century. During WWII a B-17 had to drop an average of 9,000 bombs to hit a target; in Korea and Vietnam, an F-104 had to drop 176 'guided bombs' to score a hit; during Desert Storm (1991), an F117 could hit 8 out of the 10 targets with precision-guided munitions. A Reaper drone by comparison can hit its target with a single laser-guided Hellfire missile (Kaplan, 2008). The technology is flawless; it's the human judgment that is fallible. Supporters of the drone war argue that each strike is a

product of meticulous planning among lawyers, intelligence officers, and others who scrupulously and independently confirm information about potential enemies, working to establish a rigorous 'pattern of life' to minimize the deaths of innocents. Others in the Air Force, using a classified algorithm, estimate the potential for civilian casualties based upon a variety of local data inputs (Fair, 2010). 
However, the practice of drone operations has proved far more sanguinary. A study conducted by the human rights group Reprieve has shown that in specifically targeting 24 individuals in Pakistan, drones caused a total of 874 deaths, with many of the targets reported dead on multiple occasions (Ackerman, 2014). But this toll has caused little discomfort among decision makers. With a secretive policy and docile press, and without the fear of body bags to inflame domestic opinion, democratic checks have been eroded. This, Kaag \& Kreps (2014) argue, has created a 'moral hazard' by 'shielding US citizens, politicians, and soldiers from the risks associated with targeted killings'. The myth of precision and the absence of risk make it immensely attractive for politicians to seek military solutions to political problems. Citizens are distanced from the wars fought in their names and leaders are encouraged to use force where they otherwise might exercise caution. There are no risks to incur or onerous legislative demands to meet. Success is rewarded but failure caries no sanction. Ethical concerns go out the window. In two important investigations into the deliberations behind the administration's use of lethal force, Klaidman (2012) and Mazzetti (2013) report that officials have repeatedly resolved the legal and political dilemmas of detaining terrorism suspects by having them killed instead. Drones may be successful in eliminating terrorists; but Kaag \& Kreps (2014) argue that 'the strategic ineffectiveness of drones outweighs their high tactical success rate'. This high tactical success rate, as we've noted, is a myth. The media has an obligation to dispel these myths. Only thus might the democratic checks be restored. For now, the coverage remains trapped in a vicious circle. The media underreports civilian deaths by relying on self-serving official claims; the tracking agencies aggregate these undercounts into authoritative statistics; and journalists in turn cite these statistics as a measure of the tactic's success. The public is thus kept in the dark and political reckoning is deferred.

Muhammad Idrees Ahmad is a Lecturer in Digital Journalism at the University of Stirling.

\section{References}

- Ackerman, S. (2014). 41 men targeted but 1,147 people killed: US drone strikes - the facts on the ground. The Guardian. November 24.

- Ahmad, M.I. (2011). The Magical Realism of Body Counts. Al Jazeera. June 11.

- Amnesty (2013). 'Will I be next?': US Drone Strikes in Pakistan. Amnesty International. October.

- Andreas, P. \& K.M. Greenhill (2010). Sex, Drugs, and Body Counts: The Politics of Numbers in Global Crime and Conflict. Cornell University Press.

- Becker, J. \& S. Shane (2012). Secret 'Kill List' Proves a Test of Obama's Principles and Will. The New York Times. May 29.

- Bergen, P. \& K. Tiedemann (2009). Revenge of the Drones: An Analysis of Drone Strikes in Pakistan. New America Foundation. October 19.

- Boyle, M.J. (2013). The costs and consequences of drone warfare. International Affairs 89(1): 1-29.

- Cloud, D.S. (2010). CIA drones have broader list of targets. Los Angeles Times. 5 May.

- Columbia (2012). Counting Drone Strike Deaths. Columbia Law School Human Rights Clinic. October.

- Fair, C. (2010). Drone Wars. Foreign Policy. 28 May.

- Fuller, J. (2014). Americans are fine with drone strikes. Everyone else in the world? Not so much. Washington Post. 15 July. 
- Galtung, J. \& Ruge, M. Holmboe (1965): The Structure of Foreign News. The Presentation of the Congo, Cuba and Cyprus Crises in Four Norwegian Newspapers, Journal of Peace Research, 2: 64-91.

- Harcup, T. \& Deirdre O'Neill (2001). What Is News? Galtung and Ruge revisited. Journalism Studies. 2 (2): 261-280.

- Isikoff, M. (2013). Justice Department memo reveals legal case for drone strikes on Americans. NBC News. February 4.

- Kaag, J. \& S. Kreps (2014). Drone Warfare. Polity: London.

- Kaplan, F. (2008). Daydream Believers: How a Few Grand Ideas Wrecked American Power. Wiley and Sons.

- Kilcullen, D. and A. Exum (2009). Death From Above, Outrage Down Below. The New York Times. May 16, 2009.

- Klaidman, D. (2012). Kill or Capture: The War on Terror and the Soul of the Obama Presidency. Houghton Mifflin.

- Kreps, S. (2014). Flying under the radar: A study of public attitudes towards unmanned aerial vehicles. Research \& Politics. 1 (1) April-June: 1-7.

- Lamb, C. (2006). US carried out madrasah bombing. Sunday Times. 26 November.

- McChesney, R.W. (1999). Rich Media, Poor Democracy: Communication Politics in Dubious Times. Urbana: University of Illinois Press.

- Mackey, R. (2014). Artists Try to Prick Conscience of Drone Operators With Giant Portrait of Orphan in Pakistani Field. The New York Times (The Lede). April 9.

- Mayer, J. (2009) The Predator War: What are the risks of the C.I.A.'s covert drone program? The New Yorker. October 26.

- Mazzetti, M. (2013). The Way of the Knife: The CIA, a Secret Army, and a War at the Ends of the Earth. London: Penguin Press.

- Mir, A. (2009). 60 drone hits kill 14 al-Qaeda men, 687 civilians. The News, 10 April.

- Obama, B. (2013). Text: Obama's Speech on Drone Policy. National Defence University. May 23.

- Rogers, C. (2010). Civilian Harm and Conflict in Northwest Pakistan. CIVIC. October.

- Roggio, B. and A. Mayer (2009). Analysis: A look at US airstrikes in Pakistan through September 2009. Long War Journal. October 1.

- Serle, J. (2014). Only 4\% of drone victims in Pakistan named as al Qaeda members. The Bureau of Investigative Journalism. 16 October.

- Shah, S. and P. Beaumont (2011). US drone strikes in Pakistan claiming many civilian victims, says campaigner. The Guardian, 17 July.

- Schei, T. and L. Løge, J. Lie, C. Phillips, N. Payne-Frank and J. Timberlake (2015). The Guardian Documentary: Drone wars: the gamers recruited to kill - video. The Guardian.

- Shane, S. (2012). U.S. Said to Target Rescuers at Drone Strike Sites. The New York Times. February 5.

- Singer, P.W. (2009). Wired for War: The Robotics Revolution and Conflict in the 21st Century. London: Penguin.

- Slater, E. and C. Woods (2011). Iranian TV station accused of faking reports of Somalia drone strikes. The Guardian. December 2.

- Swift, J. (1710). The Examiner (London), 15, November 2-9: 2 
- Stanford-NYU (2012). Living Under Drones: Death, Injury and Trauma to Civilians from US Drone Practices in Pakistan. International Human Rights and Conflict Resolution Clinic Stanford Law School \& Global Justice Clinic, NYU School of Law. September.

- Taylor, G. (2013). U.S. intelligence warily watches for threats to U.S. now that 87 nations possess drones. The Washington Times. November 10.

- Tuchman, G. (1972) Objectivity as Strategic Ritual: An Examination of Newsmen's Notions of Objectivity. American Journal of Sociology, 77 (4): 660-679

- Whitlock, C. (2007). The New Al-Qaeda Central. Washington Post. 9 September.

- Woods, C. (2012). Fresh evidence of CIA civilian deaths in Pakistan revealed. The Bureau of Investigative Journalism. February 27.

\footnotetext{
${ }^{1}$ For ease of reading, all news reports for a given month have been compiled into a single footnote. (1) REUTERS, 'U.S. Drone Strike,' The New York Times, January 1, 2010; (2) ISMAIL KHAN and SALMAN MASOOD 'U.S. Drone Strikes Against Militants Reported in Pakistani Tribal Area', The New York Times, January 7, 2010 (3) Declan Walsh, 'ClA drone strike missed Mehsud, say Pakistani Taliban,' The Guardian, January 14, 2010 (4) PIR ZUBAIR SHAH, 'Strike Killed Hijacking Suspect, Pakistan Officials Say', The New York Times, January 16, 2010; (5) PIR ZUBAIR SHAH, 'Pakistani Officials Say Attack By U.S. Drones Killed Up to 15, The New York Times, January 18, 2010; (6) PIR ZUBAIR SHAH, 'Drone Reportedly Killed Filipino in Pakistan,' The New York Times, January 22, 2010; (7) PIR ZUBAIR SHAH, 'Missile Strikes Kill 15 in Pakistani Tribal Region, Officials Say,' The New York Times, January 31, 2010.

2 Reports for February: (1) PIR ZUBAIR SHAH, 'U.S. Drones Said to Strike Along Border In Pakistan,' The New York Times, February 3, 2010; (2) PIR ZUBAIR SHAH, 'U.S. Missiles Kill 6 in Pakistan', The New York Times, February 15, 2010; (3) PIR ZUBAIR SHAH, 'Pakistan: Missiles Kill 8 Militants', The New York Times, February 25, 2010.

${ }^{3}$ Reports for March: (1) THE ASSOCIATED PRESS, 'Pakistan: Drone Strikes Reported', The New York Times, March 17, 2010; (2) DAVID E. SANGER, 'Drone Strike Said to Kill A Leader Of Al Qaeda,' The New York Times, March 18, 2010.

${ }^{4}$ The media's focus on form at the expense of content has at times led to equally fantastic responses. In the autumn of 2011, the Iranian state broadcaster Press TV published a series of reports in which it claimed that between September and December of that year, 1,370 Somalis had died in 56 US drone strikes. However, a BIJ investigation revealed that the numbers had been invented. The reports followed the form of mainstream drone reporting, with claims attributed to unnamed officials, but in this case the officials were as fictitious as the claims (Slater \& Woods, 2011).

${ }^{5} \mathrm{It}$ is worth noting here that one example cited by drone war supporters to prove that majority of those killed are combatants only provides further proof of the media's misreporting. In 2010, Sebastian Abbot of Associated Press used stringers to interview 80 residents of FATA about 10 drone strikes. The study claimed that of the 194 people killed 138 were militants. Christine Fair, a leading supporter of the drone war, has used this as evidence of the drones' success. However, the study merely confirmed the unreliability of initial media reports. Since in two of the attacks it confirmed civilian casualties that until then hadn't been recorded by the media (Woods, 2012).
} 